\title{
Asylum seekers and the right to access health care
}

\author{
Dallal Stevens 1
}

School of Law, University of Warwick, Coventry, UK

\begin{abstract}
$\underline{\text { Abstract }}$
In recent years, the issue of access to bealth care by asylum seekers has raised serious questions for government, the courts and the medical profession. Who has the right to medical treatment in the United Kingdom is a political, bumanitarian and human rights matter. For the government - often facing public hostility towards asylum seekers and migrants, fearful of health tourism or "pull factors" to the UK, and confronting burgeoning financial constraints - access to treatment is often regarded as a concession rather than a right. For the courts, any decision to grant treatment to non-nationals, particularly those with no right to remain, is seen as having political implications far beyond the needs of the individual. The medical profession, by contrast, prefers in the main to focus on the patient, without regard for immigration status, and is uncomfortable with a dual role. Where the balance should lie is currently being assessed by government as it considers responses to a consultation paper on Review of Access to the NHS by Foreign Nationals. At this timely point, this article offers a multidisciplinary approach to the question of access to health care by asylum seekers, by examining not only the legal position but also government policy, its impact on the individual, and, significantly, the ethical and philosophical arguments pro or contra treatment. It is contended that only through this comprehensive analysis can an appropriate legislative approach be adopted at a time when this critical social right is gaining ascendance.
\end{abstract}

\section{Introduction}

A sylum seekers, from the mid-1980s onwards, have been subjected to unparalleled executive, judicial and media scrutiny. Their motivations for seeking asylum have been examined with intense suspicion. Their ease of travel to the United Kingdom has been intentionally hindered and rights to work, to support and to remain during the asylum process have been slowly eroded, if not wholly removed. ${ }^{2}$ Those granted a right to remain are often considered to have exploited loopholes in overly liberal human rights laws with

1 Email: Dallal.Stevens@warwick.ac.uk; tel 02476523289.

2 See for a discussion of the asylum situation in the 1980s and 1990s: C Harvey, Seeking Asylum in the UK Problems and prospects (London: Butterworths 2000); P Shah, Refugees, Race and the Legal Concept of Asylum in Britain (London: Cavendish 2000); D Stevens, UK Asylum Law and Policy (London: Sweet \& Maxwell 2004). See also, for practitioners' perspective, M Symes and P Jorro, Asylum Law and Practice (London: Bloomsbury Professional 2010); I Macdonald and R Toal, Macdonald's Immigration Law and Practice (London: Butterworths LexisNexis 2010). 
the aid of politically correct lawyers. ${ }^{3}$ Their rights, some claim, have been unfairly elevated above those of the host population, of British nationals. ${ }^{4}$ In sum, many now believe that we owe the asylum seeker very little and the so-called "failed asylum seeker" nothing at all. ${ }^{5}$

The focus has recently shifted to access to health care by asylum seekers. Granting free health care to any foreign national is politically sensitive and forces one to confront controversial issues: treatment of the non-national, who has contributed little or nothing towards the NHS, can seem unnecessary and unjustified, particularly in the face of a besieged NHS facing financial stringency; access to health is often perceived as a "pull factor" encouraging non-nationals to come to the UK; as evidenced by pre-election polls in the UK in 2010, the host population is increasingly concerned about migration and its impact on key services. At the same time, there are some who regard access to health care as a right of all those on UK soil, whether national or non-national, and a mark of a civilised, human-rights-oriented society.

The decision to treat or not to treat a human being is clearly of political concern but it also raises complex legal, medical, ethical and philosophical questions. Some of these issues have been outlined in the former government's long-awaited consultation paper on the Review of Access to the NHS by Foreign Nationals, published in February 2010, and with responses currently under consideration. ${ }^{6}$ Others are discussed in part by the courts, by academics, or by NGOs. Many factors, however, remain unexplored, and the current academic literature often lacks a cross-disciplinary approach. It is thus timely to seek to place the important debate on access to health care of asylum seekers within a broad context, thereby ensuring a more comprehensive analysis than hitherto. The article evaluates the current role of law, policy and ethics, in particular the inter-relationship between the three, and draws conclusions on where the balance ought to lie. Opening with the legislation and caselaw on asylum applicants seeking health treatment in the UK, the article goes on to discuss the implications of government policy for the health of non-nationals, as well as the wider community. It then proceeds to address some philosophical arguments for and against treatment and concludes by positing that legislation, divorced from wider reflections on ethics and human rights, is misguided for the twenty-first century where the social rights of the individual are increasingly in the ascendance.

\section{Access to health care by foreign nationals: legal principles}

\section{THE LEGISLATION}

For many decades, access to health services by foreign nationals, including asylum seekers, was relatively non-contentious. The duty on the Secretary of State was to promote a comprehensive health service aimed at improving physical and mental health and

3 See, for example, J Rozenberg, "Is David Blunkett the biggest threat to our legal system?", The Daily Telegraph, 13 November 2001.

4 See the storm caused in 2007 by Labour MP for Barking, Margaret Hodge, who suggested "We prioritise the needs of an individual migrant family over the entitlement others feel they have.": M Hodge, "A message to my fellow immigrants", The Observer, 20 May 2007; F Elliot, "British families need housing priority over migrants, says Hodge”, The Times, 21 May 2007; A O’Hagan, "Shame on you, Margaret Hodge”, The Telegraph, 22 May 2007.

5 The term "refused asylum seeker" is used throughout in preference to the politically charged "failed asylum seeker".

6 Consultation closed 30 June 2010; available at: www.dh.gov.uk/publications. 
preventing, diagnosing and treating illness; ${ }^{7}$ the underlying presumption of consecutive health service statutes was that services would be free for all. ${ }^{8}$ Non-citizens were thus treated on a par with citizens and were provided with free health care where necessary. The separation between social and other rights was not at issue. Nor, ostensibly, were the resource implications of treating all those who arrive on these shores. This changed in the 1970s, but even when a power to charge "non-residents" was included in the National Health Service Act 1977, no immediate action was taken to bring it into effect (s. 121). By the 1980s, however, a shift in attitude was evident. Asylum applications were rising rapidly and the migration issue was once more singled out as a major concern for government. ${ }^{\text {? }}$ Regulations were ultimately introduced in 1989 to give effect to s. 121 and to charge "overseas visitors" for secondary health care (hospital treatment). ${ }^{10}$ Primary (general practitioner (GP)) care services remained universally free. Refugees, asylum seekers and any overseas visitor who had resided in the UK for 12 months prior to needing treatment were exempted. ${ }^{11}$ So too were certain forms of treatment. ${ }^{12}$ However, these measures were soon deemed insufficient by government and, in 2004, the radical step was taken to withdraw access to secondary health care from a broader group of overseas visitors. ${ }^{13}$

Both the 1989 and 2004 Regulations permit a health trust to charge overseas visitors in the UK for health care. The move from charging non-residents, as specified in the NHS Act 1977, to charging overseas visitors, described as those who are "not ordinarily resident in the United Kingdom", is a subtle linguistic adjustment. "Ordinary residence" has a long history, especially in the field of taxation, but is not an easy concept to define. ${ }^{14}$ There is no explanation in the NHS Act 1977 (or later legislation). Much needed clarification was provided by the House of Lords case of $R \mathrm{v}$ Barnet London Borough Council, ex parte Shah, which concerned entitlement to local authority further education grants of foreign-born students. The term "ordinarily resident" was held to mean that residence was voluntary, lawful, and for a settled purpose or purposes, and this now constitutes the standard interpretation. ${ }^{15}$ Overseas visitors are considered not to be ordinarily resident. ${ }^{16}$

The onerous legal duty of establishing whether a person is ordinarily resident or exempt from charges falls upon the individual NHS trust. In order to aid NHS trusts, the Department of Health $(\mathrm{DoH})$ issued guidance to clarify, inter alia, the position of refugees

7 See, for example, National Health Service Act 1977, s. 1; see also National Health Service Act 2006.

8 Starting with the National Health Service Act 1946.

9 See n. 2 above for a detailed analysis.

10 National Health Service (Charges to Overseas Visitors) Regulations 1989, SI 1989/306 (the 1989 Regulations).

11 Regs 4(1)(b) and (c). On the entitlement of refugees to certain rights, see, generally, J Hathaway, The Rights of Refugees under International Law (New York: CUP 2005); on whether a refugee claim can succeed on health grounds, see M Foster, International Refugee Law and Socio-Economic Rights: Refuge from deprivation (Cambridge: CUP 2007), pp. 226-35.

12 Reg. 3 and Sch. 1; Free treatment is available, for example, in emergency situations, for compulsory treatment under the Mental Health Act 1983, or for listed dangerous and transmissible diseases. HIV treatment is not exempted, though free HIV testing and counselling is available.

13 NHS (Charges to Overseas Visitors) Charging (Amendment) Regulations 2004, SI 2004/614 (the 2004 Regulations)

14 See, for an early discussion, J D McClean, "The meaning of residence" (Oct 1962) 11(4) The International and Comparative Law Quarterly 1153-68.

15 'I unhesitatingly subscribe to the view that 'ordinarily resident' refers to a man's abode in a particular place or country which he has adopted voluntarily and for settled purposes as part of the regular order of his life for the time being, whether of long or short duration." per Lord Scarman [1983] 2 AC 309, 343.

161989 Regulations, reg. 1. 
and asylum seekers. ${ }^{17}$ It stated in para. 6.24 that exemption for asylum seekers only lasts until their claim is determined and that a refused asylum seeker should be charged for a new course of treatment. It also provided that "once they have completed 12 months [sic] residence, they do not become exempt from charges" - "they" presumably refers to "failed" asylum seekers, but the guidance is poorly phrased and unclear. The advice appeared therefore to endorse the view that refused asylum seekers ought to be charged for new treatment as they were not deemed to be ordinarily resident. This was the case even where a refused applicant was unable to return home and was in receipt of support from the government (known as "section 4 hard-case support"). ${ }^{18}$

An interesting aspect of these Regulations is that there is some acceptance that an obligation is owed to asylum seekers pending determination of their claim. Although the reason for this is not articulated, it could be argued that the obligation arises from the original aim of the NHS to provide health services free at the point of need, and that no distinction should be made between, say, asylum seekers and nationals. Indeed, in 1952, Aneurin Bevan wrote that: "One of the consequences of the universality of the British Health Service is the free treatment of foreign visitors." ${ }^{\prime \prime}$ He did acknowledge that:

This has given rise to a great deal of criticism, most of it ill-informed and some of it deliberately mischievous. Why should people come to Britain and enjoy the benefits of the free Health Service when they do not subscribe to the national revenues? So the argument goes. ${ }^{20}$

For Bevan, visitors to Britain subscribed to the national revenues as soon as they started consuming certain commodities, such as drink and tobacco and entertainment. He argued that they made no direct contribution to the cost of the NHS any more than did a British citizen. ${ }^{21}$ It was unwise as well as mean to withhold the free service from a visitor to Britain. What is uncertain is whether Bevan, in referring to foreign visitors, only had lawful visitors in mind and not irregular entrants; after all, even the "illegal" migrant purchases commodities, thereby contributing to the Exchequer in the manner Bevan describes.

The truly universal view advocated by Bevan is at odds with the secondary legislation on charging of overseas visitors and the NHS Act 2006. There, the Secretary of State's duty is described as "the promotion in England of a comprehensive health service designed to secure improvement in the physical and mental health of the people of England" (emphasis added). No longer is the duty towards those in the state; they must be of the state. Yet elements of Bevan's core belief still pertain: entitlement to free health care in the Regulations is, in fact, not based on nationality, previous residence, payment of national insurance or of taxes, but on the rather peculiar legal notion of ordinary residence with its requirement of lawfulness.

The difficult moral or medical questions concerning entitlement to free health care, and at what level - primary and/or secondary - were rather lost in the debates in 1989 and 2004. The 2004 Regulations, for example, were implemented in order to deal with the hot political issue of the time: health tourism. The then Home Secretary, John Reid, put it thus:

17 DoH, National Health Service Implementing the Overseas Visitors Hospital Charging Regulations Guidance for NHS Trust Hospitals in England, January 2007 version.

18 Immigration and Asylum Act 1999, s. 4(2), grants a power to the Secretary of State to accommodate rejected asylum seekers; see also Immigration and Asylum (Provision of Accommodation to Failed Asylum-Seekers) Regulations 2005.

19 A Bevan, In Place of Fear (London: Heinemann 1952), p. 80.

20 Ibid.

21 Ibid; claims to the contrary were due, he felt, to a misunderstanding about the role played by national insurance contributions in payment for the NHS. 
If there are bona fide tourists dropping ill in the street, of course we will do what we have to do, but we are not mugs. There is a difference between being civilised and being taken for a ride. ${ }^{22}$

The crackdown would target refused asylum seekers who, in his words, were "effectively stealing treatment from the people of this country". ${ }^{23}$ When pressed, neither he nor the Minister for Public Health, Melanie Johnson, could produce concrete statistical evidence of substantial health tourism and, in particular, HIV tourism. Johnson admitted to the Select Committee on Health:

[i]t is very difficult to produce figures. Historically, figures have not been collected by the Health Service, over decades - never, basically - about levels of people using the service who are not resident or normally resident in the UK. ${ }^{24}$

The government, it emerged, did not have reliable information. ${ }^{25}$ The evidence, in fact, pointed to the opposite conclusion: many people who came into the country with HIV sought treatment long after arrival, suggesting they were not health tourists at all. ${ }^{26}$ When confronted, the minister responded with a telling change of position, declaring that amendment to the legislation was necessary to ensure that the UK did not, in future, become a magnet for health tourists. ${ }^{27}$ Here, after all, was the real concern.

The Regulations clearly apply to asylum seekers temporarily admitted to the UK, but not all those seeking asylum are granted temporary admission. ${ }^{28}$ Some are detained on arrival and sent to purpose-built fast-tracking facilities if their applications are deemed capable of being decided quickly; others who are regarded as at risk of absconding may also be detained, as may those who have reached the end of the appeal process and are due for imminent removal. ${ }^{29}$ Provision is made through secondary legislation for medical health care provision while in detention. ${ }^{30}$ Under the Detention Centre Rules, there is an obligation to assess the physical and mental health needs of detainees within 24 hours of admission. ${ }^{31}$ Medical practitioners must report the case of any detainee who may have been the victim of torture, or whose health is likely to be affected by detention, including suicidal intentions or mental health deterioration. ${ }^{32}$ The cost of health care while in detention is covered by the state.

22 BBC News, “Health tourism' rules unveiled”, 30 December 2003 http://news.bbc.co.uk/go/pr/fr//1/hi/health/3355751.stm.

23 Ibid.

24 House of Commons Health Committee, New Developments in HIV/AIDS and Sexual Health Policy, third report of session 2004-05, vol. II, 8 March 2005, HC 252-II, Q210.

25 Ibid. Q211.

26 Ibid. Q211; and see Project: London, Improving Access to Healthcare for the Community's Most Vulnerable (2007), report and recommendations, p. 12, www.doctorsoftheworld.org.uk/lib/docs/104524-report2007light.pdf.

27 See Health Committee, New Developments, n. 24 above, Q212.

28 Temporary admission is a technical term which has been described as "half way between leave to enter or remain and detention" (Macdonald and Toal, Macdonald's Immigration Law Practice, n. 2 above, para. 3.42). Anyone granted temporary admission is deemed not to have legally entered the UK.

29 See for current policy, UK Border Agency, Immigration Directorate's Instructions (November 2009), ch. 13, s.1, "Detention and detention policy in port cases", www.ukba.homeoffice.gov.uk/sitecontent/documents/ policyandlaw/IDIs/idichapter31detention/section1/section1detentionpolicyinport?view=Binary ; Enforcement Instructions and Guidance (August 2010), ch. 55, "Detention and temporary release", www.ukba.homeoffice.gov.uk/sitecontent/documents/policyandlaw/enforcement/detentionandremovals/ch apter55?view=Binary.

30 The Detention Centre Rules 2001, rr. 33-7.

31 Ibid. r. 34.

32 Ibid. r. 35. 
European Union legislation also sets out minimum standards owed to asylum seekers. The relevant directive charges member states to ensure that asylum applicants receive the necessary health care, including, at least, emergency care and essential treatment of illness. ${ }^{33}$ While the meaning of "emergency care" is self-evident, "essential treatment of illness" is less clear-cut and may vary from state to state and from clinician to clinician. A key unanswered question in the directive is whether essential treatment of illness necessitates a search for a cure or whether it is purely palliative. The directive is also less clear on obligations owed by member states to asylum applicants for mental health treatment. One issue about which there is no uncertainty is to whom the directive applies. The directive defines asylum seekers as those for whom a final decision has not yet been taken; it does not apply, therefore, to refused asylum seekers who are placed in a particularly vulnerable position vis-à-vis all "reception conditions" including health care. As will be seen from the cases referred to below, this group has been forced, in the main, to seek assistance from the courts.

The revelation that reception conditions differ widely across EU states has led the European Commission to propose recasting the Reception Directive, amongst others, ${ }^{34}$ to ensure that all states "guarantee a dignified standard of living, in line with international law". 35 The proposed recast directive extends minimum standards to all those seeking international protection, not just asylum seekers, as is contained in the current directive. Furthermore, in response to criticisms that mental health was somewhat sidelined in the 2003 directive, the clause on health care is redrafted to include mental health treatment and demands, in the case of applicants with special needs, equal provision of mental health care as for nationals. ${ }^{36}$ Given the prevalence of mental health problems amongst asylum seekers, particularly those in detention, and refugees, this amendment is to be welcomed. The UK has chosen, however, not to opt-in to the recast directives. ${ }^{37}$

33 Council Directive 2003/9/EC laying down minimum standards of reception for asylum seekers, Article 15. As well as being directly effective, the directive's principles are contained in the Asylum Seekers (Reception Conditions) Regulations 2005, SI 2005/7, Asylum Support Regulations 2000, SI 2000/704 (as amended), and the Statement of Changes in Immigration Rules (HC 395).

34 EC Commission, Proposal for a Directive of the European Parliament and of the Council Laying Down Minimum Standards for the Reception of Asylum Seekers (Recast), COM (2008) 815; EC Commission, Proposal for a Directive of the European Parliament and of the Council on Minimum Standards for the Qualification and Status of Third Country Nationals or Stateless Persons as Beneficiaries of International Protection and the Content of the Protection Granted (Recast), COM (2009) 551; EC Commission, Proposal for a Directive of the European Parliament and of the Council on Minimum Standards on Procedures in Member States for Granting and Withdrawing International Protection (Recast), COM (2009) 554; See also Green Paper on the future of the Common European Asylum System, COM (2007), p. 30. For a discussion of the UK's decisions not to opt in, see House of Lords, EU Committee, First Report on Asylum Directives: Scrutiny of the opt-in decisions, session 2009-10, HL paper 6, 4 December 2009; House of Lords, EU Committee, The United Kingdom Opt-in: Problems with amendment and codification, 7th report, session 2008-09, HL paper 55.

35 COM (2008) 815, Explanatory Memorandum, para 3.

36 Recast Article 19: (1) "Member States shall ensure that applicants receive the necessary health care which shall include, at least, emergency care and essential treatment of illness or mental disorders." (2) "Member States shall provide necessary medical or other assistance to applicants who have special needs, including appropriate mental bealth care when needed, under the same conditions as nationals." (redrafting in italics).

37 In the case of the recast Reception Directive, the reason given to the House of Lords EU Committee was that while the government intended to maintain the minimum standards currently laid down by the directive, the amendments dealing with wider access by asylum seekers to the labour market after six months, specific elements of financial support to be given to individuals, and arrangements on detention would be too onerous: EU Committee, The UK Opt-in: Problems with amendment and codification, n. 35 above, Minutes of Evidence, 25 February 2009, Q22. 


\section{THE CASE LAW}

While governmental concerns about resources and "pull factors" are not new, and are in many ways to be expected, ${ }^{38}$ the reaction of the judiciary is arguably less predictable. Courts have been called upon to adjudicate on both the narrow, technical wording of secondary legislation and the broader universal principles of human rights law. In both contexts, the impact of the decision on the life chances of the individual can be most serious.

\section{The case of $Y A$}

In April 2008, in $\mathrm{R}$ (on Application of A) v West Middlesex University Hospital NHS Trust (High Court), ${ }^{39}$ a refused asylum seeker famously challenged the lawfulness of the DoH guidance on the ordinarily resident point. A, a Palestinian, suffered from a chronic liver disease. On refusal of his asylum claim, he agreed to return to the West Bank but was unable to do so due to travel restrictions. He sought treatment from West Middlesex University Hospital but was refused surgery based on secondary legislation and the DoH's own guidance; ${ }^{40}$ in its place, he was offered painkillers. After an examination of the legislation and caselaw on ordinary residence, $\mathrm{Mr}$ Justice Mitting concluded that it was unlawful insofar as para. 6.24 advises NHS Trusts to charge refused asylum seekers who would otherwise be treated as ordinarily resident. ${ }^{41} \mathrm{~A}$, who could not leave the country, was entitled to treatment pending departure. Permission was granted to the respondent to appeal.

The press reported the case as ruling that "all asylum seekers who have not been ordered to leave the UK must be given free NHS healthcare" and that "the ruling could apply to anywhere between 200,000 and half a million people". ${ }^{42}$ Sensationalist, certainly, and statistically questionable, since the number of refused asylum seekers in the country is unknown. In response to the judgment, the $\mathrm{DoH}$ issued further instructions to NHS trusts advising that they:

must consider whether each failed asylum seeker that they treat can be considered ordinarily resident in the UK, in the same way as they would do with any other patient, taking into account the judge's opinions as to what would be likely to be sufficient proof of ordinary residence. ${ }^{43}$

Trusts were directed to delete para. 6.24 from the original guidance pending an amendment to take account of the $A$ case. They continued to be placed in the invidious position of having to check the immigration and residency status of potential patients no simple process, as made clear in $A$ where the judge referred to two contrasting House of Lords' decisions. ${ }^{44}$ Many doctors believed they had no choice about whom to treat and some managers considered that all foreign nationals were required to pay except in

38 See, for example, P Legrain, Immigrants - Your country needs them (London: Little Brown 2007) and n. 2 above.

39 [2008] EWHC 855 (Admin), 11 April 2008.

40 DoH, Guidance, n. 17 above.

41 Ibid. para. 27.

42 S Boseley, "Asylum seekers have right to full NHS care, high court rules, but government considers appeal", The Guardian, 12 April 2008.

43 Letter from R Douglas, Director General for Finance and Chief Operating Officer, DoH, to Chief Executive entitled "Subject: failed asylum seekers and ordinary residence - advice to overseas visitors managers", 1 May 2008 (available at www.dh.gov.uk/prod_consum_dh/groups/dh_digitalassets/documents/digitalasset/ dh_084480.pdf).

44 R v Barnet London Borough Council, exparte Shah [1983] 2 AC 309 and Szoma v Secretary of State for the Department of Work and Pensions [2006] 1AC 564. 
extreme emergency. ${ }^{45}$ Adam Hundt, the solicitor acting for A, stated that clients of his had died following treatment being refused. Although, as Mr Hundt rightly acknowledged, they may have died in any event, they were never given a chance to survive. ${ }^{46}$ The government appealed.

On 30 March 2009, the Court of Appeal handed down its judgment in $\mathrm{R}$ (on Application of $Y A) \mathrm{v}$ Secretary of State for the Home Department. ${ }^{47}$ After close examination of the authorities, Lord Justice Ward concluded that asylum seekers were not ordinarily resident for the purposes of the legislation. 48 "Residence by grace and favour is not ordinary", he said. "Failed asylum seekers" were in an even worse position: the judge felt that they "ought not to be here" and that "they should never have come here in the first place". 49 This striking observation seems in apparent contradiction of the universal right to seek asylum. ${ }^{50}$ While asylum seekers (and refugees) were not ordinarily resident, they were still exempted from charges under reg. 4(1)(c) of the 1989 Regulations (as amended). ${ }^{51}$ No such loophole existed for refused asylum seekers. The judge assessed whether they could be brought within another exception to charging, reg. 4(1)(b), which entitles an overseas visitor to free medical treatment following a year's lawful residence in the UK. He deduced, however, that refused asylum seekers - and, more significantly, asylum seekers - were not lawfully resident; neither was therefore entitled to free treatment as of right:

One resides here lawfully when one has the right to do so. An indulgence is granted to a claimant for asylum, not a right, and in this context the word "lawful" means more than merely not unlawful but should be understood to connote the requirement of a positive legal underpinning. Being here by grace and favour does not create that necessary foundation. 52

The connection made by the judge between lawful and indulgent residence is very telling. Temporary admission to proceed with one's asylum claim is not perceived as authority or right to reside. It is lawful presence only. ${ }^{53}$ And the right to reside is significant since it reasserts the link between territory and rights. The state grants permission to enter; the state says who is lawful or otherwise; and only when that decision is formally taken by the state can there be a question of a right to certain rights. Once an asylum claim is rejected, agency appears to return to the claimant. He or she must return to his or her own country. But what if that is not possible and the refused asylum seeker has pressing health needs? In considering whether an NHS trust has discretion to provide or withhold treatment for a refused asylum seeker, Lord Justice Ward threw the responsibility back to the health trust. In his view, it was implicit in the $\mathrm{DoH}$ guidance on the Regulations (discussed above) that there was a discretion about whether to administer or withhold treatment, even where there was no prospect of payment by the patient. How that discretion should be exercised might depend on how long a refused asylum seeker remained in the UK, particularly if he or she could not be returned to the home country;

45 BBC News, “NHS 'confusion' over asylum rules”, 1 August 2008 http://news.bbc.co.uk/go/pr/fr//1/hi/health/7537216.stm.

46 Ibid.

47 [2009] EWCA Civ 225.

48 Ibid. para. 61.

49 Ibid.

50 Universal Declaration of Human Rights 1948, Article 14(1).

51 SI 1989/306.

52 [2009] EWCA Civ 225, para. 64.

53 In the case of Szoma $\mathrm{v}$ Secretary of State for the Department of Work and Pensions [2005] UKHL 64, temporary admission was deemed lawful presence for the purposes of entitlement to welfare benefits. 
these were all details requiring further clarification in the guidance, which therefore needed amending. 54

While this judgment is viewed as disastrous by many advocates representing refused asylum seekers, it did, in fact, leave the door slightly ajar. Within days, the Director General (DG) of NHS Finance, Performance and Operation had written to all NHS trusts calling upon them to revert to the position prior to the High Court decision in April 2008. ${ }^{55}$ In his letter, the DG clarified the approach to be adopted in the case of immediate treatment, of urgent treatment, and of non-urgent treatment, applicable to all chargeable overseas visitors, not just refused asylum seekers. Following the direction provided by the court, it appears that treatment is generally advocated where the patient is unlikely to quit the UK in the near future. However, in making this evaluation, the NHS trust has to determine the future migration potential of its patients! Furthermore, as each NHS trust is free to make its own assessment, there is no guarantee of national consistency (though one might note that a "health care lottery" exists more broadly). The redrafting of the guidance on the Regulations is currently underway, alongside the review by the Home Office and DoH of access to the NHS by foreign nationals. Clarity across the board is certainly urgently required.

\section{The case of $N$}

In seeking redress for clients suffering ill health, legal advisers have not only tackled the interpretation of national rules but have also explored a human rights angle. The European Convention on Human Rights (ECHR) does not encompass a "right to health"56 as such but a number of the provisions can be used in support of health care and access to health: Articles 2, 3, 8 and 14 being the most relevant. In the case of a refused asylum seeker, the legal argument normally revolves around Articles 2, 3 and 8 in an attempt to resist removal to a state where medical treatment is unavailable or ineffective. This was the position of $\mathrm{N}$ in $N \mathrm{v} U K,{ }^{57}$ a case that has been discussed in depth, ${ }^{58}$ and that continues to have significant consequences, having adjudicated on the circumstances in which a breach of Article 3 might arise. Like $Y A$, the $N$ case concerned the politically sensitive issue of continued health treatment of a foreign national with no ostensible right to remain in the UK. As in $Y A$, the applicant was very ill but not yet at a terminal stage. Both were refused asylum seekers.

54 Ibid. para. 77. The guidance is yet to be published.

55 DoH letter to NHS trusts, 2 April 2009 available at: www.dh.gov.uk/en/Publicationsandstatistics /Lettersandcirculars/Dearcolleagueletters/DH_097384.

56 As outlined in: Universal Declaration of Human Rights (UDHR), Article 25(1): "[e]veryone has the right to a standard of living adequate for the health and well-being of himself and of his family, including food, clothing, housing and medical care and necessary social services ..."; International Covenant on Economic, Social and Cultural Rights (ICESCR), Article 12(1): "The States Parties to the present Covenant recognize the right of everyone to the enjoyment of the highest attainable standard of physical and mental health." Under Article 12(2), states are only expected to take steps necessary for: "(a) The provision for the reduction of the stillbirth-rate and of infant mortality and for the healthy development of the child; (b) The improvement of all aspects of environmental and industrial hygiene; (c) The prevention, treatment and control of epidemic, endemic, occupational and other diseases; (d) The creation of conditions which would assure to all medical service and medical attention in the event of sickness."

57 Nv UK, Grand Chamber, App. No 26565/05.

58 For further analysis of the case, see C Sawyer, "Insufficiently inhuman: removing AIDS patients from the UK” (2004) Journal of Social Welfare and Family Law 281-8; J Chalmers, Legal Responses to HIV and AIDS (Oxford and Portland, Oregon: Hart 2008), ch. 5; V Bettinson and A Jones, "The integration or exclusion of welfare rights in the ECHR: the removal of foreign nationals with HIV after N v UK" (2009) 31 Journal of Social Welfare and Family Law 83-94; V Mantouvalou, "N v UK: no duty to rescue the nearby needy?" (2009) 72 Modern Law Review 815-28. 
The facts of $N$ are now well known: the applicant, a young woman who arrived in the UK from Uganda in March 1998 apparently unaware of her condition was quickly diagnosed as HIV positive with "considerable immunosuppression and . . . disseminated mycobacterium TB". Within a week of her arrival, and while she was in hospital, she claimed asylum on the grounds of ill-treatment and rape by the National Resistance Movement in Uganda; she claimed to be associated with the Lord's Resistance Army. By August 1998, she was extremely ill having developed a second AIDS-related illness, Kaposi's sarcoma. Her asylum claim was refused in March 2001 on grounds of credibility; in addition, the Secretary of State did not consider her to be at risk from the Ugandan authorities. With no right to remain, she was subject to removal to Uganda. $\mathrm{N}$ appealed and the adjudicator dismissed the asylum claim but did allow her to appeal on the ground that her return to Uganda would breach Article 3 of the ECHR. In his view, the evidence indicated that the case for protection was "overwhelming". 59 In February 2003, the Immigration Appeal Tribunal found for the Secretary of State. ${ }^{60} \mathrm{~N}$ appealed to the Court of Appeal, ${ }^{61}$ the House of Lords, ${ }^{62}$ and then to the European Court of Human Rights (ECtHR). Following treatment with antiretroviral drugs and careful monitoring, she had stabilised and was relatively well by the time the House of Lords heard her case in May 2005. Both higher courts dismissed her case, as did the ECtHR. ${ }^{63}$

Several judges both in the UK and Strasbourg were evidently nervous about the consequences of a negative determination for N. Her prognosis on return was bleak: in the words of Lord Hope in the House of Lords, she would "face an early death after a period of acute physical and mental suffering". 64 Yet the facts of her case were determined not to be sufficiently "exceptional" to prevent removal under Article 3. N's illness had not reached the requisite advanced or terminal stage, and some level of medical care was available in her own country. Once she was differentiated from the applicant in the earlier case of $D \mathrm{v} U K^{65}$ her chances of success were poor. D, by contrast, was regarded as having been "critically ill" appearing "close to death", and could not be guaranteed any nursing or medical care in his country of origin, nor had any family there willing or able to care for him or provide him with even a basic level of food, shelter or social support. ${ }^{66}$

The uncompromising effect of the judgment is severe. Individuals suffering serious ill health and with no right under immigration or asylum law to remain in a signatory state will be removed in the vast majority of cases. The interpretation of earlier ECtHR case law by the majority, in particular $D \vee U K,{ }^{67}$ ensures that the economic - and perhaps political interests of signatories far outweigh the medical needs of the individual; for human suffering to be deemed sufficiently exceptional to override state interests, it will have to be verging on the nigh unattainable. And with advances in medicine, the exact scenario in $D$ is unlikely to be repeated: such is the tragic irony for $\mathrm{N}$ and those in a similar position.

It is arguable that both the Strasbourg court and the House of Lords were engaging in "real-jurisprudence": Contracting states should not be led too far down the path of positive obligations, particularly one as far reaching as health provision with its onerous financial

59 N v Secretary of State for the Home Department [2005] UKHL 31, para. 6.

60 [2002] UKIAT06707 - HX05310-02.

61 N v Secretary of State for the Home Department [2004] INLR 10, para. 40 per Laws LJ.

$62 \mathrm{Nv}$ Secretary of State for the Home Department [2005] UKHL 31.

63 N v UK, Grand Chamber, App. No. 26565/05.

64 N v Secretary of State for the Home Department [2005] UKHL 31, para. 20.

65 Dv UK (1997) EHRR 423.

66 Nv UK, Grand Chamber, App. No 26565/05, see paras 39 and 42.

67 Dv UK (1997) EHRR 423. 
implications, for fear that to do so might prompt withdrawal from the ECHR. States may well consider the $N$ decision a victory for common sense and the public purse, but it provides a limited analysis of the complexity surrounding health care access and makes only passing reference to the difficult underlying ethical and political issues. Lord Justice Sedley hints at such concerns elsewhere in ZT v Secretary of State for the Home Department and his comments are worth citing in full:

When in Nv Home Secretary, \$14, Lord Nicholls described these questions as "not capable of satisfactory humanitarian answers" he might have added "or jurisprudential ones". If HIV were a rare affliction, readily treatable in the UK but not treatable except for the fortunate few in many other countries, the courts would have little hesitation in holding removal of sufferers to such countries to be inhuman treatment contrary to Article 3. It is the sheer volume of suffering now reaching these shores that has driven the Home Office, the Immigration Appellate Authority and the courts to find jurisprudential reasons for holding that neither Article 3 nor Article 8 can ordinarily avail HIV sufferers who face removal. Only cases which markedly exceed even the known level of suffering an example is the expectant mother in CAv Home Secretary [2004] EWCA Civ 1165 - now qualify for protection.

We have in consequence had to set the bar in both Article 3 and Article 8 cases unusually high for removal cases. The reasoning of the House in $N$ accepts, in effect, that the internal logic of the Convention has to give way to the external logic of events when these events are capable of bringing about the collapse of the Convention system. ${ }^{68}$

So while the judge acknowledges the reality and extent of the suffering, he is unable to assist the vast majority of sufferers for practical reasons - namely, the political and legal consequences for the ECHR if the courts liberally sanction treatment. He does not quantify the number of HIV sufferers that it might be regarded as acceptable to treat within a contracting state, such as the UK. The stringent requirement of exceptionality suffices to ensure that very few are permitted to remain on health grounds under Article 3.

While $N$ was concerned with HIV, its findings have now been extended to other medical conditions, including mental health. In KH (Afghanistan) v Secretary of State for the Home Department, the appellant, a young man from Afghanistan, applied for asylum and was rejected. ${ }^{69} \mathrm{He}$ then raised mental health problems as a basis for a fresh claim to remain in the UK: there was considerable evidence of depression, symptoms of post-traumatic stress disorder, self-harming, and a future risk of suicide, particularly if the appellant were returned to Afghanistan. The Secretary of State decided that the new material did not constitute a fresh claim for immigration purposes. Discussion in the Court of Appeal revolved around two issues: (i) whether the case should be treated as medical - which the court felt it should; and (ii) whether there was a divide between the jurisprudence of $\mathrm{Nv}$ $U K$ and Pretty v $U K^{70}$ - which it did not consider pertinent in view of the fact that the $N$

68 [2005] EWCA Civ 1421, Court of Appeal, 27 November 2005, paras 41 and 42.

69 [2009] EWCA Civ 1354, Court of Appeal, 14 December 2009.

7035 EHRR 1. 
jurisprudence was the later more considered view of the Strasbourg court and was specifically applicable to mental illness cases. ${ }^{71}$ To be permitted to stay, therefore, $\mathrm{KH}$ needed to show that his circumstances were exceptional as per $N$, or, as Lord Justice Sedley suggests, he suffered from a "rare affliction". This he failed to do. The court said:

The truth is that the presence of mental illness among failed asylum seekers cannot really be regarded as exceptional. Sadly even asylum seekers with mental illness who have no families can hardly be regarded as "very exceptional" . . Perhaps a very old or very young person would qualify but hardly an ordinary adult. ${ }^{72}$

Unfortunately, there is much evidence to suggest that the stress and insecurity created by applying for asylum, the lengthy wait for a decision, the possibility of detention, and the fear of removal all contribute significantly to mental health problems of this vulnerable group. ${ }^{73}$ For mental health issues, then, to be labelled as unexceptional for the purposes of Article 3, when they might in fact have been caused or exacerbated by the asylum process itself, is a sad indictment of the asylum system in the UK.

\section{The case of Ama Sumani}

The cases of $N$ and $Y A$ are the starkest reminders of the impact of restricted health care access: the serious decline in health and possible death of an individual. Both decisions received press coverage and some notoriety, but it is the plight of Ama Sumani, that caught the public attention, once more highlighting the complex issues at stake. Though this was not a case involving an asylum seeker, the outcome would have been the same had she sought asylum and been refused. Ama Sumani, a widowed 39-year-old Ghanaian mother of two who was suffering from terminal cancer, was removed to Ghana in January 2008 after her appeals failed. She arrived in the UK in 2003 on a visitor's visa which was changed to a student visa as she intended to enrol on a banking course; it transpired, however, that her English was not adequate. Contrary to the conditions of her admission, she started working. She travelled to Ghana in 2005 to attend a memorial service for her husband and, on her return to the UK, her student visa was revoked but she was granted temporary admission. In January 2006, she was diagnosed with multiple myeloma and a case was made to the Home Office to allow her to remain on compassionate grounds. This was rejected and removal took place once her doctors deemed her fit to travel. The apparent lack of the requisite treatment in Ghana, accompanied by her inability to pay, guaranteed an early death for Ms Sumani, and so it proved. Despite many donations to assist her, which enabled her to receive dialysis treatment shortly after arriving in Ghana, she died in hospital in Accra on 19 March 2008. For many, the removal of such an ill woman was scandalous, as reflected in a forthright editorial of The Lancet.

To stop treating patients in the knowledge that they are being sent home to die is an unacceptable breach of the duties of any health professional. The UK has

71 [2009] EWCA Civ 1354, Court of Appeal, 14 December 2009, para. 28; Pretty, a non-migration case, held in para. 52, that: "The suffering which flows from naturally occurring illness, physical or mental, may be covered by Article 3, where it is, or risks being, exacerbated by treatment, whether flowing from conditions of detention, expulsion or other measures, for which the authorities can be held responsible (see the above mentioned D. v. the United Kingdom and Keenan v. the United Kingdom judgments and also Bensaid v. the United Kingdom, no. 44599/98, (Sect. 3), ECHR 2000-I."

72 Ibid. para. 33 .

73 See, for example, Mind, Improving Mental Health Support for Refugee Communities (London: Mind 2009); Mind; A Civilised Society - Mental health provision for refugees and asylum-seekers in England and Wales (London: Mind 2009); A Keller et al., "Mental health of detained asylum seekers" (2003) 362 The Lancet, issue 9397, 1721-3. 
committed an atrocious act of barbarism. It is time for doctors' leaders to say so - forcefully and uncompromisingly. ${ }^{74}$

In summary, the caselaw to date establishes that jurisprudential reasons will be found to ensure that access to health care is limited for those who have failed to obtain legal entitlement to remain. The courts are not prepared to disaggregate a state's obligation to provide health care from lawful residence, unless government itself chooses to do so, as in the exemption provided to asylum applicants. Human rights arguments will rarely reverse such an outcome and the courtroom is seldom a forum for moralising, unless, implicitly, about the ongoing primacy of state sovereignty.

\section{Access to health care: government policy}

For the government, decisions such as that of the High Court in $A$ are extremely troubling. " [I]t cannot be right" stated the Parliamentary Undersecretary of State on Health "that someone living in the UK without any authority should have the same inalienable right of access to services as someone living here with that authority". 75 On the other hand, one could argue, the morality of refusing treatment for someone suffering painful, debilitating or life-threatening diseases, but who is unable to leave the UK through no fault of his or her own, is certainly questionable. The government's response to this point has, hitherto, been limited. It has focused largely on the perceived burden on the UK taxpayer and NHS service user of migrants and asylum seekers in need of health care. Asylum seekers have long been regarded as a threat to a sovereign state in many ways - mainly because they are seen as uninvited, largely "bogus" and seriously resource-intensive. ${ }^{76}$ Refused asylum seekers pose a double threat: they have failed to prove any entitlement to call upon our hospitality, yet they may disappear or be difficult to remove. Refused asylum seekers who are incapacitated are most vilified - they are often deemed exploitative, abusive, undeserving, a drain on resources, and, at worst, a serious risk to health.

Yet, a humanitarian approach is not completely counter-intuitive to politicians. In a surprising move in May 2008, and following the decision in $A$, the Welsh Assembly government decided to provide NHS services free of charge to refused asylum seekers. In the face of some stringent opposition, Welsh Health Minister, Edwina Hart, declared that the mark of a civilised society was how it treated its sick and dying:

I'm simply looking at the human being at the end of the chain and saying if they've got severe health problems and they require help and assistance, as a civilised country we should give it. ${ }^{77}$

This appeal to a hitherto unacknowledged morality was a new departure. Yet, many of her Welsh constituents were unmoved, complaining that the NHS could not cater for its own UK citizens, never mind foreigners. Fears were also voiced that the policy would act as a pull factor to the world's migrants, not least from England into Wales. ${ }^{78}$ Such concerns were ignored. In July 2009, the Welsh Assembly amended reg. 4(1)(c) of the principal 1989

74 "Editorial" (19 January 2008) 371 The Lancet 178.

75 Letter from Ann Keen MP to Lord Avebury, 28 July 2008.

76 See Stevens, UK Asylum Law and Policy, n. 2 above, for a discussion of the history of asylum seeking to the UK.

77 BBC News, "Failed asylum seekers' free NHS”, 20 May 2008 http://news.bbc.co.uk/go/pr/fr//1/hi/wales/7409265.stm.

78 D Williamson, "Free NHS services for failed asylum seekers 'won't drain resources", Western Mail, 21 May 2008 www.walesonline.co.uk/news/wales-news/2008/05/21/free-nhs-services-for-failed-asylum-seekerswon-t-drain-resources-91466-20939869/. 
Regulations to ensure that refused asylum applicants would not be charged in Wales for services forming part of the health service. ${ }^{79}$

While Wales appeared to buck the trend, the UK government continued to explore further restrictions on health access for overseas visitors. Thus, in 2004, a case was made to bring the rules on access to primary health care into line with those on secondary health care, and charging, amongst others, refused asylum seekers as if they were private patients, unless the treatment was emergency or immediately necessary. ${ }^{80}$ The then government's position was that GP practices should already be charging refused asylum seekers for non-emergency care. However, since GP practices can, if they wish, register a patient without consideration being given to asylum or immigration status, considerable variability exists between practices on how they handle overseas visitors. The government had hoped to address this anomaly.

Though many organisations objected in the strongest possible terms to the withdrawal of primary health care, ${ }^{81}$ the government seemed unmoved, announcing, in June 2007, a joint review of the rules on access to health care by the DoH and the Home Office. Under consideration, once more, was the withdrawal of free access to primary health care from certain categories of "overseas visitors", including "failed" asylum seekers. Doctors and lawyers maintained that: any change to the law could endanger the lives of torture survivors who had been refused asylum but who qualified for hard-case support; ${ }^{82}$ medical practitioners would be placed in an unacceptable ethical position; 83 there was a very high level of stress-related physical illness, depression and anxiety amongst those seeking immigration and asylum advice; and applicants who did not have free medical treatment were often unable to present the best possible case to the Home Office or on appeal. ${ }^{84}$

The legal and medical professions were not alone in their doubts. A reported disagreement between the Home Office and $\mathrm{DoH}$ on the best way to proceed delayed publication of the conclusions of the 2007 review. 85 The alleged "wrangling throughout Whitehall" apparently came to a head when The Observer newspaper reported that the

79 National Health Service (Charges to Overseas Visitors)(Amendment)(Wales) Regulations 2009, SI 2009/1512 (W 148).

80 DoH consultation paper, Proposals to Exclude Overseas Visitors from Eligibility to Free NHS Primary Medical Services, May 2004, in which it was stated: "The Government is considering changing and more clearly defining the rules on the eligibility of overseas visitors to free NHS primary medical services . . to make the rules more transparent for the person accessing those services and for the frontline staff in practices and Primary Care Trusts (PCTs) who operate them." (para. 2.1); see also Annex A, para. 14.

81 For example, the Refugee Council, the Medical Foundation for the Care of Victims of Torture, the BMA, and the Immigration Law Practitioners' Association (ILPA). See also, Global Health Advocacy Project, Four Years Later: Charging vulnerable migrants for NHS primary medical services, June 2009, available at www.medsin.org/downloads/page_attachments/0000/2384/Four_Years_Later.pdf, pp. 29-30; J Doward, "Failed asylum seekers face health care ban", The Observer, 2 December 2007.

82 Medical Foundation for the Care of Victims of Torture, "Revisions on health care threaten to increase vulnerability of torture survivors", 8 November 2007, available at www.torturecare.org.uk/news/ latest_news/1289.

83 See the online petition by doctors: "We are appalled by government plans to further restrict the rights of [refused asylum seekers] to primary care. This would impose serious health risks on them and on the general public. It would also interfere with our ability to carry out our duties as doctors. It is not in keeping with the ethics of our profession to refuse to see any person who may be ill, particularly pregnant women with complications, sick children or men crippled by torture. No one would want such a doctor for their GP. We call on the government to retreat from this foolish proposal, which would prevent doctors from investigating, prescribing for, or referring such patients on the NHS.": available at www.gopetition.co.uk/petitions/medicaljustice-for-asylum-seekers.html.

84 ILPA, ILPA's Response to: Proposals to exclude overseas visitors from eligibility to free NHS primary medical services, 13 August 2004.

85 G Hinsliff, "GPs demand right to treat refugees”, The Observer, 3 August 2008. 
government was ready to scrap the plans after accepting that there was, after all, no concrete evidence that free primary health care was an inducement to seek asylum in England and Wales. ${ }^{86}$ Final confirmation of a possible stand-down emerged in July 2009 with the announcement that there would not, in fact, be any significant changes to either primary or secondary health care. Rather, in autumn 2009, a number of proposals were put forward for further public consultation:

- asylum seekers whose claim has been refused but who are being supported because there are recognised barriers to their return home should be exempt from charges;

- unaccompanied children, including those in local authority care, should be exempt from charges;

- UK residents may be absent from the country for up to six months in a year before being considered for charges for NHS hospital treatment;

- working with the UK Border Agency to recover money owed to the NHS and exploring options to amend the Immigration Rules so that visitors will normally be refused permission to enter or remain in the United Kingdom if they have significant debts to the NHS;

- investigating the longer-term feasibility of introducing health insurance requirements for visitors. ${ }^{87}$

The then government also promised to commission further research on the current policy of charging non-residents for HIV treatment beyond the initial diagnosis and counselling. ${ }^{88}$

The very clear impetus of the two consultation papers published in February 2010 Review of Access to the NHS by Foreign Nationals ${ }^{89}$ and Refusing Entry to Stay to NHS Debtors 90 - was the on-going anxiety about health tourism, despite the lack of concrete evidence, as indicated earlier. There also appeared to be a perception that some refused asylum seekers are worthier of free treatment than others - namely those receiving basic welfare support (under s. 4) after refusal of their claim; not all agree. Dr Vivienne Nathanson, Head of Science and Ethics at the British Medical Association (BMA), said:

We believe no-one whose asylum claim has been refused should be turned down for care which cannot be delayed, and which clinicians determine they need. Doing so affects our ability to control communicable disease, and ultimately puts additional pressure on the NHS, particularly on emergency services. ${ }^{91}$

It should be noted, however, that while the BMA supports access to "immediate and necessary care" by foreign nationals, it is not in favour of free access to all NHS services. ${ }^{92}$

86 G Hinsliff, "GPs win care fight for asylum seekers", The Observer, 12 October 2008.

87 See DoH and Home Office statement of 20 July 2009, available at http://www.dh.gov.uk/en/News/ Recentstories/DH_102993.

88 HC Hansard, Ministerial Statement, 20 July 2009, col. 97WS; J Meikle, "Government plans crackdown on 'health tourism"', The Guardian, 20 July 2009.

89 Available at: www.dh.gov.uk/en/Consultations/Liveconsultations/DH_113233; see also, on same webpage, Draft NHS Guidance on Implementing the Overseas Visitors Hospital Charging Regulations, and Draft National Health Service (Charges to Overseas Visitors) Regulations 2010.

90 Here, amendments to the Immigration Rules are proposed to make non-payment of NHS charges specific grounds for refusal of entry or further stay in the UK. Available at www.ukba.homeoffice.gov.uk/ sitecontent/documents/aboutus/consultations/nhs-debtors/consultation-document.pdf?view=Binary.

91 http://web.bma.org.uk/pressrel.nsf/wlu/SGOY-7U5GFW?OpenDocument\&vw=wfmms.

92 www.bma.org.uk/whats_on/annual_representative_meeting/arm09_tuesday/arm09bmanewstuesday06.jsp. 
The consultation ended on 30 June 2010, and the new Liberal Democrat-Conservative Coalition appears happy to proceed with the review as outlined.

\section{IMPACT OF POLICY}

\section{Non-detention}

A number of valuable reports and studies have identified specific problems faced by refused asylum seekers and other migrants. ${ }^{93}$ Many of the stories make distressing reading. Quite a number of migrants (and others) who were entitled to free services were unable to gain access due to the incorrect application of the Regulations by service providers. This was particularly true of maternity services for "failed" asylum seekers Though maternity services fall under the exception for treatment that is "immediately necessary", the DoH guidance on maternity care was not always followed. Women can be charged for such treatment, but they should always be treated irrespective of their eligibility for free treatment or ability to pay. ${ }^{94}$ The same principle applies to other categories of overseas visitors. While the provision of early and preventive care through primary care helps avoid expensive hospital treatment later, people suffering from cancer, diabetes, trauma and HIV/AIDS had been turned away from care; as a result, some were unable to work, study or care for the family, or even suffered very painful deaths. In addition, the public health risks appeared to be disregarded: those with communicable diseases such as HIV were not receiving adequate advice and treatment and were therefore likely to spread infection or disease. The researchers found no evidence of health tourism; in fact, the majority of people needed access to primary care or antenatal services rather than expensive specialist treatment. It was concluded that barring GP access would inevitably increase the pressure on accident and emergency departments and the pull-factor argument was weak since most European countries were providing better health care to migrants than the UK. ${ }^{95}$

In a further development, Iain Duncan-Smith MP, 96 former chair of the Centre for Social Justice (CSJ), ${ }^{97}$ has championed greater rights for asylum seekers. In an extensive report, Asylum Matters: Restoring trust in the UK asylum system, published in December 2008, the CSJ analysed the current asylum system with a view to improving removal or integration of applicants following the asylum decision. The report sought to "put an end to the current 'black hole' of destitution and illegal working that so many asylum seekers fall into within the UK". 98 On the specific issue of health, it observes:

Denial of free access to health care for failed asylum seekers could be dangerous for the whole community, even if those barriers are perceived and not real. Communicable disease might not be identified and treated within the asylum seeking community if it was thought that they were not eligible to access

93 Refugee Council, First Do No Harm: Denying health care to people whose asylum claims have failed: www.refugeecouncil.org.uk/Resources/Refugee \%20Council/downloads/researchreports/Healthaccessreport _jun06.pdf; Médecins du Monde UK, Improving Access to Healthcare for the Community's Most Vulnerable: Report and recommendations 2007: www.doctorsof the world.org.uk/lib/docs/10452-report2007light.pdf.

94 See DoH, Table of Entitlement to NHS Treatment (correct as of May 2008).

95 Médecins du Monde UK, Improving Access, n 93 above, pp. 4-6, ; for a recent analysis of health care for undocumented migrants, see Médecins du Monde European Observatory on Healthcare, Access to Healthcare for Undocumented Migrants in 11 European Countries, 2008 survey report, September 2009: www.mdmuk.org.uk/lib/docs/121111-europeanobservatoryfullreportseptember2009.pdf.

96 Former Conservative Party leader and, currently, Secretary of State for Work and Pensions.

97 An organisation he founded in 2004 to "put social justice at the heart of British politics".

98 CSJ, Asylum and Destitution Working Group, Asylum Matters: Restoring trust in the UK asylum system (London: CSJ December 2008), "Preface": www.centreforsocialjustice.org.uk/client/downloads/Asylum\% 20Matters $\% 20$ Full $\% 20$ Report $\% 20 \_W e b \% 20$ New_.pdf. 
treatment, or if there was a breakdown of trust between GP practices and asylum seekers who wanted to avoid detection from the authorities. ${ }^{99}$

Significantly, the report calls for practical and sensible solutions to help lift refused asylum seekers out of the trap of destitution into which so many fall:

For those asylum seekers that have been refused but cannot be returned home, a temporary licence for paid employment and the opportunity to contribute to their own support is recommended. This temporary right should entitle the asylum seeker free access to primary and secondary health care as well as access to English Language Classes. It should be reviewed every year. ${ }^{100}$

It is notable that this proposal links employment with entitlement to access health care. This could be regarded as counter to Bevan's original vision, but more in line with the views of those who find the resourcing implications of such a positive obligation antithetical. Despite Duncan-Smith's membership of the current government, the right to work for asylum seekers is not being embraced with alacrity. Indeed, following a recent Supreme Court judgment granting refused asylum seekers with fresh claims of a right to seek employment, ${ }^{101}$ the Immigration and Borders Minister, Damian Green, is seeking to restrict the jobs for which asylum applicants can apply to industries with staff shortages. ${ }^{102}$

\section{Detention}

While much of the focus on the health care of asylum seekers has centred on those with temporary admission, a number of reports have also questioned the standard of mental and physical care administered in fast-track detention and removal centres, ${ }^{103}$ and some have highlighted actual ill-treatment within the detention estate itself. ${ }^{104}$ A Medical Justice ${ }^{105}$ study of 56 refused asylum seekers held in detention found that torture victims had been "neglected and re-traumatised by detention in the UK"106 and that many detainees were "denied treatment for serious medical conditions", including a number with tuberculosis. Detainees had been denied HIV tests and results, while those who were HIV positive often had their treatment disrupted during detention. Children and pregnant women who were being deported to high-risk malarial areas were not always offered appropriate prophylaxis or bed nets, and hunger strikers, objecting to conditions in detention, were found to be in "imminent danger of organ failure". The reported findings related not only to physical ailments: many detainees were found to be depressed or to have post-traumatic stress disorder, and were at risk of self-harming or attempted suicide. Children are particularly

99 CSJ, Asylum Matters, n 98 above, para. 4.7.

100 Ibid. "Executive summary", para. 7.7.

$101 \mathrm{R}$ (on the application of ZO (Somalia)) v Secretary of State for the Home Department [2010] UKSC 36.

102 A Travis, "Home Office bids to restrict jobs for asylum seekers", The Guardian, 29 July 2010.

103 See P Aspinall and C Watters, Refugees and Asylum Seekers: A review from an equality and buman rights perspective, research report No 52 (London: Equality and Human Rights Commission 2010), ch. 3; HM Chief Inspector of Prisons, Report on an Unannounced Full Follow-up Inspection of Yarl's Wood Immigration Removal Centre, 9-13 November 2009: www.justice.gov.uk/inspectorates/hmi-prisons/docs/Yarls_Wood_2009_rps.pdf

104 See, for example, Medical Justice et al., Outsourcing Abuse: The use and abuse of state-sanctioned force during the detention and removal of asylum seekers, July 2008, and subsequent government-commissioned report in response, Baroness N O'Loan, Report to the UKBA on "Outsourcing Abuse", March 2010: www.medicaljustice.org.uk/images/stories/reports/reportonoutsourcingabuse.pdf; see also Medical Justice, Beyond Comprehension and Decency: An introduction to the work of medical Justice, July 2007.

105 In 2005, Medical Justice, a registered charity, was established to provide independent medical and legal advice and representation to detained asylum seekers. It also promotes change to policy and practice in detention and removal centres.

106 See n. 104 above. This is contrary to the guidelines of the Istanbul Protocol (Manual on the Effective Investigation and Documentation of Torture and Other Cruel, Inhuman or Degrading Treatment or Punishment, 9 August 1999). 
prone to psychological damage from incarceration ${ }^{107}$ and, as a consequence, the present government has pledged to end the detention of children for immigration purposes. ${ }^{108}$

It is evident from these and other findings ${ }^{109}$ that, despite excellent work undertaken by many medical practitioners working in the detention estate, there are some real concerns about assessment and treatment of those in detention, ${ }^{110}$ and about the perceived high level of mental health problems. ${ }^{111}$ One of the possible reasons for sub-standard health care in detention is that management of removal centres is contracted out to Serco Ltd, G4S Group and GEO Group, ${ }^{112}$ and medical services are provided by private companies such as Drummonds Medical Support Services and Serco Health. Though health care in detention is monitored through health needs assessments, and inspection by the Chief Inspector of Prisons, the commissioning of health care by the Home Office rather than the $\mathrm{DoH}$ is regarded by some as deeply problematic and will remain so until the NHS is fully responsible for the health of immigration/asylum detainees. ${ }^{113}$

\section{Access to health care: some ethical and philosophical considerations}

As is clear from the discussion so far, the UK government upholds certain obligations towards refugees and those seeking asylum, but often regards others - amongst whom are the majority of refused asylum seekers - as outwith its responsibility. For its part, the judiciary has interpreted the law narrowly, permitting non-nationals to be treated for medical conditions only in the most "exceptional circumstances" when they have no right

107 According to a report by Medical Justice in September 2010, two-thirds of children became ill or were injured after being held in detention. See also the Children's Commissioner, The Arrest and Detention of Children Subject to Immigration Control, February 2010, and the Royal Colleges of Paediatrics and Child Health, General Practitioners and Psychiatrists and the UK Faculty of Public Health, Intercollegiate Briefing Paper, "Significant harm: the effects of administrative detention on the health of children, young people and their families": www.rcpsych.ac.uk/press/pressreleases2009/immigrationdetention.aspx.

108 Queen's Speech, 25 May 2010.

109 For a useful recent study of detention in Europe, see Jesuit Refugee Service-Europe, Becoming Vulnerable in Detention, June 2010: www.jrseurope.org/publications/JRS-Europe_Becoming\%20Vulnerable $\% 20$ In\%20Detention_June\%202010_PUBLIC_28Jun10.pdf.

110 See, for example, the complaint lodged with the General Medical Council against three doctors working at Yarl's Wood removal centre relating to numerous accusations of poor patient care: K McVeigh, "Demand for investigation of three doctors at Yarl's Wood", The Guardian, 22 March 2010; see also the reports of HM Chief Inspector of Prisons available at: www.justice.gov.uk/inspectorates/hmi-prisons/immigration-removalcentre-inspections.htm

111 See K Robjant, R Hassan and C Katona, "Mental health implication of detaining asylum seekers: systematic review" (2009) 194 British Journal of Psychiatry 306-12.

112 There are currently 11 immigration removal centres. Serco is responsible for the running of Colnbrook and the problematic Yarl's Wood removal centre. GS4 operates Dungavel, Oakington, Tinsley House and Brook House removal centres. GEO runs Campsfield House and Harmondsworth. The rest are managed by HM Prison Service.

113 Interview with Dr Frank Arnold, Medical Justice, June 2010. In 2008, a Report on Healthcare in Private Immigration Removal Centres was undertaken to examine, inter alia, the transfer of commissioning services to the NHS. While this was not formally recommended, a number of significant changes were proposed: www.medicaljustice.org.uk/images/stories/reports/csip $\% 20$ report $\% 20$ private $\% 20 \mathrm{irc} \% 5 \mathrm{C} \% 27 \mathrm{~s}$.pdf. The DoH issued guidelines in January 2010 on the clinical management of people refusing food in immigration removal centres and prisons: www.dh.gov.uk/prod_consum_dh/groups/dh_digitalassets/@dh/@en/@ps/ documents/digitalasset/dh_111690.pdf). 
to remain in the UK. ${ }^{114}$ Their reasons for so doing often appear policy-based, rationalised on the basis of unwillingness to elevate social, economic and cultural rights to the status of civil and political, or for fear of over-burdening signatory states. While lauded by some as the triumph of realism, such an approach, it is contended, is limited. It fails to examine all aspects of the argument in the globalised world of the twenty-first century, particularly questions of morality and responsibility. If, as the judiciary suggests, it is inappropriate to impose seemingly burdensome obligations on states to treat certain non-nationals requiring medical attention, ${ }^{115}$ it is essential to examine the ethical grounds for such a position certainly more than has been done hitherto. It can no longer be acceptable to hide behind restrictive legal reasoning when such fundamental moral questions are at stake and when state-centred notions of justice are no longer accepted as inviolable.

At a legal and philosophical level, the notion of a generic "right to health" is widely debated and contested, even when applied to a state's own citizens. ${ }^{116}$ Some regard a "right to health" - implying as it could a right to "be healthy" - as rather meaningless, without obligation, preferring in its place a "right to the highest attainable standard of health" 117 or a "right to health care" alongside a "right to health conditions", which do imply a duty. 118 This suggests granting "the right to a number of health-related services, claims and freedom, taking into account the available resources of a State and the health needs of its people". 119 These can entail significant demands upon a state. ${ }^{120}$ Others contend strongly that it is a basic human right without which an individual is unable to realise his or her

114 See further EM (Lebanon) (FC) (Appellant) (FC) v Secretary of State for the Home Department [2008] UKHL 64 in which $N$ v UK was cited as indicative of justified restriction: "Yet even in such a case [involving Article 3], where there was a very real risk that the harm that would result from the applicant's expulsion to the inferior system of health care in her country of origin would reach the severity of treatment prescribed by that Article, the court held that, other than in very exceptional cases, there was no obligation under the Convention to allow her to remain here. This was because it was not the intention of the Convention to provide protection against disparities in social and economic rights. To hold otherwise, even in an Article 3 case, would place too great a burden on the Contracting States.": Lord Hope, para. 10.

115 This is often a hypothetical assumption, not economically costed or factually evaluated.

116 A full analysis of these issues is outside the remit of this article. See, for wider discussion: J Harrington and M Stuttaford (eds), Global Health and Human Rights: Legal and philosophical perspectives (Abingdon: Routledge forthcoming 2010); S Anand, F Peter and A Sen (eds), Public Health, Ethics, and Equity (Oxford: OUP 2004); N Daniels, Just Health Care (New York: CUP 1985); N Daniels, Just Healtb: Meeting needs fairly (New York: CUP 2008); S Gruskin et al. (eds), Perspectives on Health and Human Rights (New York: Routledge 2005).

117 As per Article 12(1) of the 1966 ICESCR, which delivers a "right to health" in the following terms: "The States Parties to the present Covenant recognize the right of everyone to the enjoyment of the highest attainable standard of physical and mental health." For further information on the legal right to health see the website of the International Federation of Health and Human Rights Organisations, which contains, inter alia, the reports of the UN Special Rapporteur on the right of everyone to the enjoyment of the highest attainable standard of physical and mental health, Paul Hunt (2002-08): www.ifhhro.org/.

118 M Kirby, “The right to health fifty years on: still sceptical?” (1999) 4 Health \& Human Rights 13; J Asher, The Right to Health: A resource manual for NGOs (London: Commonwealth Medical Trust 2004); Office of the UN High Commission for Human Rights/World Health Organisation, The Right to Health, Factsheet 31, available at www.ohchr.org/Documents/Publications/Factsheet31.pdf.

119 B Toebes, The Right to Health as a Human Right in International Law (Antwerpen: Intersentia/Hart 1999), p. 19.

120 See the description of "Key aspects of the right to health" contained in Factsheet 31, n. 118 above, pp. 3-6. 
potential or is often (but not always) unable to live in dignity. ${ }^{121}$ More recently, there has been growing support for considering access to health care alongside the issue of poverty, under an umbrella of social or distributive justice, thereby avoiding theoretical disputes about the meaning and content of a "right to health". 122

While the notion of a right to health, or indeed any economic, social or cultural right, can be seen as morally problematic, even as between state and citizen, such a right is arguably more contentious when understood to involve the provision of health care by a state to non-citizens or "foreigners".123 General Comment 14 of the Committee on Economic, Social and Cultural Rights (CESCR) on the Right to the Highest Attainable Standard of Health (Article 12) has no such doubts. It explicitly states that:

States are under the obligation to respect the right to health by, inter alia, refraining from denying or limiting equal access for all persons, including. . . . asylum seekers and illegal immigrants, to preventative, curative and palliative health services. ${ }^{124}$

This may be the position from a human rights perspective but it does not necessarily encompass the range of philosophical perspectives. Naturally, there are numerous theoretical positions vis-à-vis the treatment of foreigners, in its non-medical sense, within a state. It is therefore the intention here to consider some of the more significant arguments in order to provide the crucial ethical and philosophical contexts to the specific debate on access to health services by asylum seekers.

\section{REASONS TO TREAT FOREIGNERS}

For advocates of the right to health (care), the right is fundamental, enabling each individual to realise his or her full potential, thereby satisfying the Rawlsean notion of "equality of fair opportunity" 125 as developed by Norman Daniels. ${ }^{126}$ With this as a central premise, it follows that all, wherever they are based, should be entitled to exercise this right. But acceptance of the premise alone accomplishes little. An answer is still required to some core questions: for the right to health (care) to be effective, a judgment must be made on who bears the duty, what contribution should be made towards health improvement, and for whom? These issues can be addressed at a global or a national level. Some concepts of justice presume that there is a moral duty to assist those who are worse off or in need through no

121 Clearly, many who are ill and/or suffering are able to live dignified lives. For the commitment that "health is a fundamental human right indispensable for the exercise of other human rights", see, inter alia, ICESCR, General Comment 14, "The right to the highest attainable standard of health" (Article 12), 25 April-12 May 2000, E/C.12/2000/4, ICESCR, para. 3: "[t]he right to health is closely related to and dependent upon the realization of other human rights ... including the rights to food, housing, work, education, human dignity, life, non-discrimination, equality, the prohibition against torture, privacy, access to information, and the freedoms of association, assembly and movement." See also the special issue of The Lancet, vol. 372, issue 9655, 13 December 2008, focusing on the right to health, and H Shue, Basic Rights, Subsistence, Affluence and US Foreign Policy (Princeton NJ: Princeton UP 1980).

122 See n. 116 above, and S Hurley, "The 'what' and the 'how' of distributive justice and health" in N Holtug and K Lippert-Rasmussen (eds), Egalitarianism: New essays on the nature and value of equality (Oxford: Clarendon Press 2006), ch. 13; N Daniels, "Health-care needs and distributive justice" (1981) 10(2) Philosophy and Public Affairs 146-79.

123 See, for broader analysis, D Weissbrodt, The Human Rights of Non-citizens (Oxford: OUP 2008); for a useful compilation of the international legal documents relevant to migration and health see International Organization for Migration, Migration and the Right to Health: A review of international law, International Migration Law No 19, available at: http://publications.iom.int/bookstore/free/IML_19.pdf.

124 ICESCR, General Comment 14, n. 121 above, para. 34, see www2.ohchr.org/english/bodies/cescr/index.htm.

125 J Rawls, A Theory of Justice (Cambridge, Mass: Harvard UP 1999), s. 14.

126 Daniels, Just Health Care, n. 116 above. 
fault of their own. National boundaries do not lessen such a duty. The duty exists on account of the humanity of those in need, irrespective of where in the world they might be situated. One of the more famous pleas for such an expansive, impartial moral obligation was provided by Peter Singer in 1972 in his article entitled "Famine, affluence and morality"; in it, he reflected on the nature of the obligations, if any, of affluent states or their citizens towards the (distant) poor. ${ }^{127} \mathrm{He}$ argued that proximity makes no moral difference in the obligation of the affluent to assist the starving and favoured a utilitarian concept of cosmopolitanism:

I begin with the assumption that suffering and death from lack of food, shelter, and medical care are bad. ... if it is in our power to prevent something bad from happening, without thereby sacrificing anything of comparable moral importance, we ought, morally, to do it. ${ }^{128}$

Critics of Singer tend to dispute that there is an equivalent obligation to assist both a stranger and a neighbour's child. ${ }^{129}$ Certainly, this seems, at the very least, counter-intuitive and unrealistic, and in a more recent piece, Singer acknowledges that:

Very few human beings can live happy and fulfilled lives without being attached to other particular human beings. To suppress these partial affections would destroy something of great value, and therefore cannot be justified from an impartial perspective. ${ }^{130}$

However, his acceptance of a degree of partialism is somewhat limited and may not include a neighbour's child over a stranger.

Since Singer's 1972 article, moral and political philosophers have increasingly assessed the duties owed to the distant needy, and, as a consequence, the arguments pro and contra have been wide-ranging and myriad. ${ }^{131}$ At the forefront are those theorists who have sought to develop plausible theories based on principles of distributive justice, utilitarianism, liberalism, or human rights. Much of the discussion in the literature has focused on the scourge of poverty and how to achieve equality of opportunity for all human beings. While some have rejected a global equality of opportunity, ${ }^{132}$ many cosmopolitan and global justice theorists believe that justice can only be achieved through greater distribution of resources from developed (rich) states to the less developed (poorer) states; they argue that rich states bear a greater responsibility towards the poor, on account of their former colonialist or current political and economic activities (described by Thomas Pogge as a "negative duty"). ${ }^{133}$ Similar lines of argument can surely be employed in relation to health. Poor health and poverty are often closely intertwined. If it is accepted that states, or individuals within those states, owe cross-border duties to help alleviate poverty, it is a short step to suggesting that a similar responsibility is owed in relation to health, particularly

127 P Singer, "Famine, affluence and morality" (1972) 1 Philosophy and Public Affairs 229-43.

128 Ibid. p. 231.

129 Singer stated that: “it makes no moral difference whether the person I help is a neighbour's child ten yards from me or a Bengali whose name I shall never know, ten thousand miles away': ibid.

130 P Singer, "Outsiders: our obligations to those beyond our borders" in D K Chatterjee (ed.), The Ethics of Assistance: Morality and the distant needy (Cambridge: CUP 2004), p. 16.

131 See, for example, Shue, Basic Rights, n. 121 above; J Rawls, The Law of Peoples (Cambridge, Mass: Harvard UP 1999); Chatterjee, The Ethics of Assistance, n. 130 above; S Caney, Justice Beyond Borders (Oxford: OUP 2005); A Buchanan, Justice, Legitimacy and Self Determination (Oxford: OUP 2004); D Miller, National Responsibility and Global Justice (Oxford: OUP 2007); K-C Tan, Justice Without Borders (Cambridge: CUP 2004).

132 See, for example, Miller, National Responsibility, n. 131 above, and Shue, Basic Rights, n. 121 above, who discusses an argument in favour of prioritising compatriots on account of their nationality, at least in the case of a duty to provide aid.

133 T Pogge, World Poverty and Human Rights (Cambridge: CUP 2002). 
where, as Pogge suggests, foreigners' medical conditions are due to "avoidable poverty engendered by global economic institutions". ${ }^{134}$

Within the global justice framework outlined above, the question of proximity is seen as broadly immaterial; the (health) suffering of all - like poverty - is of moral import to each of us. Yet proximity or distance is also often identified as a significant factor in establishing or denying moral obligations. ${ }^{135}$ Proximity can imply, inter alia, economic, political, cultural, racial, familial or geographic closeness. For the purposes of health care provision, geographic proximity may seem the most pertinent. Morally, the decision to offer treatment could be regarded as far less problematic in relation to foreigners already in the $\mathrm{UK}$ as for those based outside. In the case of the foreign national who reaches the UK and asks to be treated by the NHS, such an obligation could be said to arise on account of spatial proximity. The greater moral claim over that of his or her compatriots still living in the country of origin arises simply on account of physical presence in the territory of the host state; the encounter between stranger and national creates a moral relationship, ${ }^{136}$ biblically equivalent to the parable of the Good Samaritan. ${ }^{137}$ Proximity, therefore, has normative significance. Clearly, the relational proximity that is said to exist between compatriots, and which does not exist between foreigner and citizen, could be prioritised over geographical proximity to limit any moral obligation to treat the foreigner present in the host state. However, the suggestion that there is something special about the relationship between fellow-citizens can be questioned. Most would agree that there are special duties owed to close family, but beyond this close-knit group, it becomes, for some, increasingly difficult to defend partiality towards friends, neighbours, compatriots. The health concerns of the distant foreigner are as relevant as those of the near, or, in fact, of fellow countrymen.

An alternative case for treating foreigners in the UK, whatever their circumstances, might be made under the principle of hospitality, though this is perhaps the least convincing moral argument. Here we do not mean simply the Kantian view of hospitality 138 - the right of the stranger not to be treated with hostility - nor the biblical commandment to be hospitable to strangers, ${ }^{139}$ but the remarkable unconditional hospitality imagined by Jacques Derrida:

absolute hospitality requires that I open up my home and that I give not only to the foreigner (provided with a family name, with the social status of being a foreigner, etc.), but to the absolute, unknown, anonymous other, and that I give place to them, that I let them come, that I let them arrive, and take place in the place I offer them, without asking of them either reciprocity (entering into a pact) or even their names. ${ }^{140}$

134 T Pogge, "Relational conceptions of justice: responsibilities for health outcomes" in S Anand, F Peter and A Sen (eds), Public Health, Ethics, and Equity (Oxford: UP 2004).

135 See, for wide-ranging discussion, the full volume of The Monist, July 2003, which considers "Moral distance", and Chatterjee, The Ethics of Assistance, n. 131 above; see also, Singer, "Famine", n. 127 above; P Nortvedt and M Nordhaug, 'The principle and problem of proximity in ethics' (2008) 34 Journal of Medical Ethics 156-61.

136 See S Reader, "Distance, relationship and moral obligation” (July 2003) The Monist 367-81.

137 See J Waldron, "Who is my neighbour?: Humanity and proximity" (July 2003) The Monist 333-54.

138 "Hospitality means the right of a stranger not to be treated as an enemy when he arrives in the land of another. One may refuse to receive him when this can be done without causing his destruction; but, so long as he peacefully occupies his place, one may not treat him with hostility.": I Kant, Perpetual Peace: A philosophic sketch (1795), Third Definitive Article for a Perpetual Peace.

139 For example, Hebrews 13:2.

140 J Derrida and A Dufourmantelle, Of Hospitality (Chicago: Stanford UP 2000), p. 25. 
Under this vision of hospitality, one would admit the foreigner without question and treat the foreigner as an equal in one's "place" - be that home, town, state. What might this mean, then, for entitlement to basic needs? Such absolute hospitality would necessitate treating the foreigner unconditionally as one's own; if hungry, there would be an obligation to feed; if unwell, there would be an obligation to administer treatment. To some extent, one could argue that current rules on treatment of foreign nationals in the UK pays partial credence to such a principle, in so far as certain vulnerable foreigners - such as asylum seekers - are entitled to free health care; present policy fails, however, to be all encompassing and is unlikely ever to be so.

A principle of hospitality may be closely aligned to the belief in the inherent human dignity of all people, as can a cosmopolitan stand-point. Endorsement of "human dignity" is prevalent in human rights instruments and is understood, generally, to mean:

that each human being possesses an intrinsic worth that should be respected, that some forms of conduct are inconsistent with respect for this intrinsic worth, and that the state exists for the individual not vice versa. ${ }^{141}$

This approach to human dignity could certainly support an argument in favour of providing equal free medical treatment to citizens and non-citizens alike where failure to treat could be regarded as an affront to human dignity. Indeed, the Welsh Health Minister's justification for providing free health care to refused asylum seekers was expressed in such humanitarian terms:

I'm simply looking at the human being at the end of the chain and saying if they've got severe health problems and they require help and assistance, as a civilised country we should give it. ${ }^{142}$

Ultimately, the cases of $N$ and Ama Sumani can also be seen in this light: removal to Uganda or Ghana and the certainty of (a painful) death does not appear to respect the intrinsic worth of the individual. While this interpretation of human dignity is not universal, for the moment, there is no consensus on the definition of "human dignity", despite its wide usage in international and European law.

Alongside moral philosophy, medical ethics has a significant contribution to make to the debate. ${ }^{143}$ Traditional biomedical ethics, as conceived by Beauchamp and Childress, is generally regarded as comprising four elements: autonomy, ${ }^{144}$ beneficence - acting in the best interests of the patient - non-maleficence, ${ }^{145}$ and justice. ${ }^{146}$ For many doctors, beneficence is the most important principle, though inevitably constrained by the other three. ${ }^{147}$ Such constraint, particularly when imposed by a duty of justice, can create practical problems. As Gillon suggests, doctors may accept as part of their moral purpose not only the health of their patients, but the health of all sick people. ${ }^{148}$

If they do so, they clearly commit themselves and medical ethics to require justice in the distribution of resources: justice not only for their patients, not only for their country's

141 C McCrudden, "Human dignity and judicial interpretation of human rights" (2008) 19 European Journal of International Law 655, at 723.

142 BBC News, "Failed asylum seekers", n. 77 above.

143 See the seminal works of R Gillon, Philosophical Medical Ethics (Chichester: John Wiley \& Sons 2000) and of T Beauchamp and J Childress, Principles of Biomedical Ethics (Oxford: OUP 2001).

144 This requires respect for the individual and his or her ability to make decisions regarding his or her health.

145 The ethical principle of doing no harm (similar to the principle of primum non nocere, "first do no harm", and to the classic version of the Hippocratic Oath: "from what is to their harm and injustice I will keep them").

146 Beauchamp and Childress, Principles, n. 143 above.

147 Gillon, Philosophical Medical Ethics, n. 143 above, p. 74.

148 Ibid. p. 78. 
patients, but for all the world's sick, present and future (and even perhaps the world's potentially sick). ${ }^{149}$

Such a commitment to justice, which for many is requisite for medical practice, could influence treatment decisions about non-nationals, asylum seekers, refused asylum seekers, and would result in a radical redistribution of resources. ${ }^{150}$ From a justice perspective, society would need to choose to which moral value it gave priority, taking account of autonomy, beneficence, non-maleficence, as well as possible judgments on equity, impartiality and fairness. ${ }^{151}$

The medical community has long recognised a need to provide further guidance on universal ethical principles and the prevailing trend is to base these on human rights norms. The 2005 UNESCO Universal Declaration on Bioethics and Human Rights, for example, calls for full respect for human dignity and human rights, ${ }^{152}$ but also states that "the interests and welfare of the individual should have priority over the sole interest of science or society". 153 Such prioritisation of the individual qua individual would seem to justify the treatment of non-nationals on an equal basis as citizens, similar to arguments based on justice, humanitarianism or human dignity. Yet the human rights paradigm has not always been welcomed within the medical community, 154 especially when seen as somehow usurping the traditional framework. For its part, the Ethics Department of the BMA has issued guidance on "Doctors and asylum seekers"155 and on "Access to health care for asylum seekers and refused asylum seekers", 156 in which it repeats its view that "the timely provision of appropriate care to this vulnerable group of patients" is based on both humanitarian and public health arguments. It is the health needs of the individual that are of paramount import.

\section{SOME REASONS NOT TO TREAT (REFUSED) ASYLUM SEEKERS}

Nationals of a state, it might be argued, owe few obligations to non-nationals who have been granted no permission to remain on the state's territory. But on what basis? Clearly, the notion of a bounded duty can be traced to the notion of bounded territory particularly that derived from the creation of the modern state. Within the modern state, nationality is regarded as "the paramount form of social identity", 157 the principle being that "everyone who resides permanently in the territory should share in a common national identity, and that this identity should override other characteristics that might cause social boundaries to be drawn differently, whether within the state or between states". ${ }^{158}$ Citizens within this nation-state system might be prepared to look after one another through a

149 Gillon, Philosophical Medical Ethics. n. 143 above.

151 Ibid. p. 98.

152 Article 3(1).

153 Article 3(2).

154 See for a discussion of pros and cons, J Mann, "Medicine and public health, ethics and human rights" (1997)

27 The Hastings Centre Report 6-13; P Farmer and N Gastineau, "Rethinking health and human rights: time for a paradigm shift" (2002) 30(4) Journal of Law, Medicine and Ethics 655-66; TA Faunce, "Will international human rights subsume medical ethics? Intersections in the UNESCO Universal Bioethics Declaration" (2005) 31(3) Journal of Medical Ethics 173-8; dedicated volume (2009) 34(3) Journal of Medicine and Philosopby, critiquing the UNESCO Declaration, in particular R Andorno, "Human dignity and human rights as a common ground for global bioethics", 223-40.

155 BMA, The Medical Profession and Human Rights: Handbook for a changing agenda (London: Zed Books/BMA 2001).

156 2008, available at: www.bma.org.uk/ethics/asylum_seekers/asylumhealthcare2008.jsp.

157 D Miller and SH Hasmi (eds), Boundaries and Justice: Diverse ethical perspectives (Princeton NJ; Princeton UP 2001), p. 5.

158 Ibid. 
variety of means, including redistribution, but they are less likely to feel anything much is owed to non-nationals. Citizens take priority. Michael Walzer famously articulated such a view as the right of the community to decide its own membership; for him, a community of citizens was "the ideal political order". ${ }^{159}$ Yet he also recognises the limitations of such "communitarian justice" when confronted by the particular problem presented by asylum seekers: "Are citizens bound to take in strangers?"160 Should victims of political or religious persecution be admitted? 161 While recognising that some duty might be owed to refugees, his response seeks to be practical as well as humanitarian and, as such, is arguably of limited assistance to the asylum seeker, who lives in a limbo world of uncertain status. Without doubt most states - at least the most developed - will favour the "right to restrain the flow" over any moral considerations to protect all those seeking sanctuary:

The call "Give me ... your huddled masses yearning to breathe free" is generous and noble; actually to take in large numbers of refugees is often morally necessary; but the right to restrain the flow remains a feature of communal selfdetermination. The principle of mutual aid can only modify and not transform admission policies rooted in a particular community's understanding of itself. ${ }^{162}$

Walzer's communitarianism is not alone in prioritising citizenship. Nationalists too, such as David Miller, strongly favour a society built upon the mutual historical, linguistic and cultural bonds that are said to exist between citizens; it is these bonds that give rise to greater obligations: "nations are ethical communities ... The duties we owe to our fellow-nationals are different from, and more extensive than, the duties we owe to humans as such."163 Indeed, while "the claims of would be immigrants must be recognised", for Miller "they do not have to be counted in the same way as the interests of those who are already citizens, including their interests in self-determination". 164 But immigrants are not asylum seekers. Miller advocates a generous approach towards "refugees" - those he describes as "people who have fled their home country as a result of well-founded fear of persecution or violence"; 165 a state has an obligation to let in a refugee applying for admission. ${ }^{166} \mathrm{He}$ even, somewhat remarkably, goes on to argue that "there is clearly a good case for broadening the definition to include people who are being deprived of rights of subsistence, basic health care, etc". 167 While this view is considerably more munificent than the current legal or political position vis-à-vis refugees, there are limits to his generosity. Reflecting Walzer's views, he suggests that states must be given "considerable autonomy to decide how to respond to particular asylum applications", taking a range of factors into consideration such as overall numbers and the demands placed on the host population. ${ }^{168}$ Ultimately, the human rights of refugees cannot override the legitimate claim of a state that its obligation to admit refugees has been exhausted, even if resulting in tragic consequences. ${ }^{169}$

159 M Walzer, "Response to Chaney and Lichtenburg" in P Brown and H. Shue (eds), Boundaries: National autonomy and its limits (Totowa: Rowman \& Littlefield), p. 101.

160 M Walzer, Spheres of Justice (Oxford: Blackwell 1983), p. 45.

161 Ibid. p. 49.

162 Ibid. p. 51.

163 D Miller, Citizenship and National Identity (Cambridge: Polity Press 2000), p. 27.

164 Miller, National Responsibility, n. 131 above, p. 223.

165 Ibid. p. 225.

166 Ibid.

167 Ibid.

168 Ibid. pp. 226-7.

169 Ibid. p. 227. 
Following this line of reasoning, if a proper assessment has been undertaken of a state's ability to cope, which should include demand on resources such as education, housing and health care, refugees - and, presumably, asylum seekers as well - should be admitted so long as the state's own citizens are not inordinately jeopardised by such a policy. Putting aside for the moment the immense difficulty of justly determining who is a "refugee", once admitted, what then should happen? Is it justified to prioritise fellow citizens over foreigners in the provision of health care? Utilitarians might favour denying a universal "right to health" if its fulfilment is so resource-intensive as to undermine the greater good. This could lead to a prioritisation of entitlement dependent on migration status or the length of connection with the state. In this scenario, the order of priority might be: citizens; refugees and longterm immigrants with indefinite leave to remain; refugees with limited leave (currently five years); asylum seekers during the determination period of their claim; refused asylum seekers who cannot leave due to no fault of their own; and those with no right to remain, awaiting deportation, subject to removal. In many ways, this approach reflects current government policy.

While partiality towards compatriots is a tenable moral stance under nationalism, and permits differential health treatment; conversely, impartiality may also lead one to conclude that the foreigner reaching the shores of the UK is not deserving of preferential treatment. If it were shown that the money spent on saving one foreigner in poor health in the UK such as a case akin to $N$ - could in fact save many more suffering similarly in a developing country, then most would prefer to save the greater number. ${ }^{170}$ To conclude otherwise might be considered illogical. Furthermore, it has been contended that even liberal theory ${ }^{171}$ other than perhaps liberal universalism - struggles with the issues raised by borders and national self-interest. ${ }^{172}$ Liberal realism dictates that "a liberal democracy cannot sustain a welfare system or other liberal institutions without restricting membership and access" and therefore, though counter-intuitive for many liberal theorists, restricting access to the NHS to citizens is the only morally acceptable outcome. ${ }^{173}$ Ultimately, for both those in favour of treating (refused) asylum seekers, and those against, the issue will come down to a decision on the best distribution of resources. It will be rare that there be agreement on moral priorities. Perhaps the best that can be hoped for in any decision on health is careful consideration of all the fundamental moral, ethical and public health principles.

\section{Conclusion and outlook}

Migration forces one to confront head on major themes such as sovereignty, membership, rights and justice. The reluctance by many theorists, until recently, to attend fully to the consequences of migration for a theory of justice has been surprising. ${ }^{174}$ This lacuna is now beginning to be filled. ${ }^{175}$ However, there are many outstanding issues to be resolved, one of which is the relationship between migration and health care. Health care provision is, in

170 I am grateful to Victor Tadros for this point.

171 Which commits itself to the moral equality of all persons.

172 P Cole, "Human rights and the national interest: migrants, health care and social justice" (2007) 33 Journal of Medical Ethics 269, at 272.

173 Ibid.

174 The most notable is Rawls in The Law of Peoples, $\mathrm{n} .131$ above, who restricts discussion to a footnote: "a people has at least a qualified right to limit immigration, I leave aside here what these qualifications might be”, p. 39, n. 48.

175 See for, example, S Benhabib, The Rights of Others: Aliens, residents and citizens (Cambridge: CUP 2004); P Cole, Philosophies of Exclusion: Liberal political theory and immigration (Edinburgh: Edinburgh UP 2000); H Lindahl (ed.), A Right to Inclusion and Exclusion?: Normative fault lines of the EU's area of freedom, security and justice (Oxford: Hart 2009). 
its own right, a political and ethical minefield. ${ }^{176}$ Decisions on the equitable distribution of scarce healthcare resources by the state for its own citizens are fraught with difficulty and have given rise to considerable debate. When questions emerge on the application of a right to health to non-nationals, or on the economics or politics of treating various categories of migrant, the answers can often be controversial and the consequences divisive. Some contend that assistance to a suffering individual takes priority over all else; others of a more practical persuasion point to limited resources and to the inability of the UK to offer succour to the world's less fortunate.

The law in this area has largely endorsed the interests of politicians. There is no obligation to treat those who have no right to remain. The hugely noble sentiments of the International Bill of Rights, ${ }^{177}$ as well as the ECHR, to place human dignity before all else and to treat all human beings as equal have repeatedly been declared unrealistic, particularly as far as certain social, economic or cultural rights are concerned. Such a view was candidly articulated by Lord Hope in a 2008 non-health case: EM(Lebanon) (FC)(Appellant) (FC) v Secretary of State for the Home Department (Respondent). ${ }^{178}$ Offering his (arguably distorted) summary of the decision in $N$, he said:

In $N$ v United Kingdom a distinction was drawn between civil and political rights on the one hand and rights of a social or economic nature on the other. Despite its fundamental importance of the Convention system, article 3 does not have the effect of requiring a Contracting State to guarantee unlimited health care to all aliens who are without a right to stay within its jurisdiction.

In an apparent volte-face, the previous government appeared to stall its proposals to withdraw access to primary health care from refused asylum seekers, amongst others, and suggested a more generous approach to refused asylum seekers who cannot leave the country through no fault of their own. The change in heart towards certain categories of refused asylum seekers in the statement of July 2009 was an important development. It recognised that not all refused asylum seekers can depart the UK immediately their claim is turned down, and that there should be some ongoing entitlement to health care. This seems based on moral principles - on the needs of the suffering individual - rather than a belief in a right to health as such. Until recommendations in the ongoing review are implemented, the current policy persists: to permit asylum seekers access to (limited) health care during the course of the asylum claim but to make every effort to return refused asylum seekers who can be removed. There is also some acknowledgment now of the implications of nontreatment for public health. In the words of the former Health Minister, Ann Keen: "These measures strike the right balance between controlled access, the protection and promotion of wider public health, and ensuring that the health care of the most vulnerable groups are [sic] protected."'179

The tension between what is perceived as just and what is perceived as practical within a liberal democracy, highlighted so starkly in the $N$ case, endures. On World Aids Day in December 2008, the former Labour MP, Neil Gerrard, then chair of the all-party parliamentary group on refugees, criticised the contradiction inherent in government policy of the day: on the one hand, the UK had pledged, alongside other G8 members, to help poor states obtain access to universal drugs for AIDS; on the other, it continued to deport

176 As evidenced by the debate on health care reform in the US.

177 UDHR and two covenants.

178 [2008] UKHL 64.

179 Statement by Minister for Health, "Access to NHS services for foreign nationals", 20 July 2009 : www.dh.gov.uk/en/MediaCentre/Pressreleasesarchive/DH_102993; see also HC Deb, col 97WS, 20 July 2009. 
HIV patients, with no right to remain in the UK, to their countries of nationality, often with the certain knowledge that such action would be seriously detrimental to health. Gerrard put it thus:

I think when you have got someone who has been put on treatment here and then they are removed back to a country where they can't get treatment, it is virtually a death sentence. ${ }^{180}$

In an inspirational appeal to mercy, the Archbishop of York, John Sentamu, suggested that the famous "neighbour principle" from Donoghue v Stevenson"181 might assist us in determining which duties we owed one another within society. Reflecting on the case of Ama Sumani, he said:

What would have been the consequences of applying Lord Atkin's "Neighbour Principle" to Ama Sumani? Sadly the separation of Religion, Morality and the Law has gone too far, leading to such dire unintended consequences. Did those responsible "take reasonable care to avoid acts or omissions which they could reasonably foresee would be likely to injure" her? Was she "a person so closely and directly affected by [their] acts that [they] ought reasonably to have them in contemplation?" Clearly if Lord Atkin's neighbour principle had been applied in this case, Mrs Sumani might well still be alive today. ${ }^{182}$

While many might concur with Archbishop Sentamu's compassionate message, in practice, the expanded duty of care he advocates is unlikely to be realised beyond the field of negligence. Government appears reluctant to engage fully with the complex medicoethical issues at stake. The judiciary continues to back away from creating a universal right to (free) health care, or from applying Article 3 to non-national healthcare cases without the sanction of Parliament. Currently, then, no principle of hospitality, egalitarianism, global justice, or even human dignity is likely to rescue those whose permission to remain continues to be viewed, in the words of Lord Justice Ward, as an "indulgence", however worthy their cause or pressing their need. ${ }^{183}$ As shown by this article, the importance of a multidisciplinary approach to the subject of health access by asylum seekers cannot be denied. It is only through a comprehensive assessment of law, policy, medicine and ethics that one can hope to arrive at a fitting response to this and other social rights for the twentyfirst century. The recent move towards treatment for hard-case refused asylum seekers is a move in the right direction.

180 S Boseley, "Britain is criticised for deporting HIV patients", The Guardian, 1 December 2008.

181 [1932] AC 562

182 Address by the Archbishop of York John Sentamu to the Evangelical Alliance, "The road to recovery: neighbourliness and mercy, community and service", the Royal Society, 28 November 2008: www.archbishopofyork.org/2042?q=immediately.

183 See n. 52 above. 